\title{
Competition for Aphid Prey between Different Lady Beetle Species in a Laboratory Arena
}

\author{
Christy Leppanen, ${ }^{1,2}$ Andrei Alyokhin, ${ }^{2}$ and Serena Gross ${ }^{2,3}$ \\ ${ }^{1}$ U.S. Fish and Wildlife Service, Pacific Islands Fish and Wildlife Office, 300 Ala Moana Boulevard, P. O. Box 50088, Honolulu, \\ HI 96850-5000, USA \\ ${ }^{2}$ School of Biology and Ecology, University of Maine, Orono, ME 04469-5722, USA \\ ${ }^{3}$ Department of Entomology, Purdue University, 901 West State Street, West Lafayette, IN 47907-2089, USA
}

Correspondence should be addressed to Andrei Alyokhin, andrei.alyokhin@umit.maine.edu

Received 19 August 2011; Accepted 5 October 2011

Academic Editor: Michael Rust

Copyright () 2012 Christy Leppanen et al. This is an open access article distributed under the Creative Commons Attribution License, which permits unrestricted use, distribution, and reproduction in any medium, provided the original work is properly cited.

\begin{abstract}
Direct competition for aphid prey (Hemiptera: Aphididae) was evaluated between and among several lady beetle species (Coleoptera: Coccinellidae). The behavior of three native (Coccinella trifasciata, Coleomegilla maculata, and Hippodamia convergens) and four nonnative (Coccinella septempunctata, Harmonia axyridis, Hippodamia variegata, and Propylea quatuordecimpunctata) lady beetles was observed in laboratory arenas. The beetles were kept alone, paired with conspecifics or paired with heterospecifics, and presented with potato aphids (Macrosiphum euphorbiae). Harmonia axyridis was the most successful aphid predator in our study, being able to find aphids more quickly and consume more of them compared to most other lady beetle species. It was also by far the most aggressive of the tested species. Coccinella septempunctata, C. trifasciata, and C. maculata generally followed $H$. axyridis in aphid consumption. Prey discovery, consumption, and aggressive behaviors were dependent on which species were present in the arena. Except for the generally superior $H$. axyridis, there was no obvious dominance hierarchy among the other tested species and no dichotomy between the native and non-native species. Asymmetric interactions between lady beetle species may affect their abilities to coexist in the same habitat.
\end{abstract}

\section{Introduction}

Lady beetles comprise an ecologically and economically important group of insects that are also charismatic and well known to the general public $[1,2]$. Understanding intraguild interactions among lady beetle species is important both for their conservation and for their maximum utilization as biological control agents. For example, the establishment of nonnative lady beetle species often coincides with declines in native lady beetle abundances [3-9] and has been implicated in having profound effects on the populations of pestiferous prey $[4,9,10]$.

Competition is often assumed when predatory species consuming the same prey species are found in the same area [11]. Persistent species that share prey and an evolutionary history are often considered to have achieved a compromise over time, allowing them to coexist by differentially exploiting the same prey species $[12,13]$; for example, by foraging at different times [14]. When species consuming the same prey are newly brought together, the ability of each to acquire the same necessary resources may allow for their coexistence $[15,16]$. Intraguild predation, however, does not mean that a sufficient share goes to each predator [6, 17-19]. Consumption by a more efficient predator may eventually result in the competitive exclusion of the less efficient predator $[16,20]$.

Most comparative studies of different lady beetle species have either dealt with their relative abundances in the field $[3-9,21]$ or focused on intraguild predation $[3,6,7,17,22-$ 32]. The recent spread of Harmonia axyridis (Pallas) outside of its native range has been the impetus for a number of additional behavioral comparisons [33]. Harmonia axyridis has been shown to outcompete other lady beetle species in evaluations of intraguild predation [17, 24, 31], prey utilization [6], pathogen tolerance [34], and in the acquisition of prey tended by aggressive ants [35]. Relatively little research effort has been dedicated to competition for prey items among lady 
beetle species. In an extensive field survey, Finlayson et al. [21] documented native and nonnative lady beetle species occurring together in a variety of habitats throughout Maine. A series of experiments [35, 36, and this study] were then conducted to compare behavior between different species. In the present study, we investigated behavior of seven lady beetle species competing for prey in a laboratory arena. We hypothesized that recently introduced species that share habitats with the native species [21], but appear to replace them over time [9], are more aggressive aphid predators.

\section{Materials and Methods}

2.1. Study Species. Aphidophagous lady beetle species, which were known to be abundant in Maine and were found together in the same habitats $[21,36]$, were chosen for the present study. Three species are native: the three-banded lady beetle Coccinella trifasciata perplexa Mulsant, the twelve-spotted lady beetle Coleomegilla maculata lengi Timberlake, and the convergent lady beetle Hippodamia convergens Guérin. The native range of $C$. trifasciata is north from New Jersey to Labrador and west to California and Alaska [37]. Coleomegilla maculata is native to eastern North America from Georgia to Ontario, and west to Texas and Minnesota [37]. The range of $H$. convergens extends from British Columbia and Ontario to South and Central America and the Antilles [37].

The nonnative lady beetles used in the present study were the seven-spotted lady beetle Coccinella septempunctata (L.), the multicolored Asian lady beetle Harmonia axyridis (Pallas), the variegated lady beetle Hippodamia variegata (Goeze), and the fourteen-spotted lady beetle Propylea quatuordecimpunctata (L.). Harmonia axyridis is native to Central and Eastern Asia [33, 38]. The other three species are of Palearctic origin $[39,40]$. All were inadvertently or intentionally introduced into North America. Coccinella septempunctata has been established in the eastern United States since 1979 [41]. Harmonia axyridis was first documented as established in North America in 1988 [42, 43] and now occurs throughout much of the continental United States [33]. Hippodamia variegata is widespread throughout northeastern North America [44-49]. In Maine, P. quatuordecimpunctata was first documented in 1988 in Aroostook, Penobscot, and Kennebec Counties, where it is believed to have expanded its range from populations in Quebec dating to1968 [50].

The potato aphid, Macrosiphum euphorbiae (Thomas), served as the prey. Macrosiphum euphorbiae is common in Maine and native throughout North America [51]. It is known to feed on over 200 plant species, including potato, apple, aster, and rose [51] and is a common prey item for many lady beetle species $[2,37,52]$.

2.2. Insect Origins and Maintenance. Lady beetles were collected 48-72 hours before the initiation of each trial and were provided with water, but no food, for 48 hours before trials began. Beetles were collected in Orono, Maine $\left(44.8835^{\circ} \mathrm{N}\right.$, $68.6721^{\circ} \mathrm{W}$ ) from a variety of habitats: mixed shrub (Solidago sp., Rubus sp., Prunus sp., Rosa sp., Cornus sericea, and Alnus sp.), apple (Malus sp.), grain (Hordeum sp. and Avena sp.), mixed organic crops (Solanum lycopersicon, Allium sp., Brassica sp., Pisum sp., and Phaseolus sp.), and field (Phleum pratense, Trifolium sp., Cirsium sp., Vicia sp., and Fragaria sp.). Potato aphids were obtained from a colony maintained in our laboratory. The colony was originally founded from aphids collected in Presque Isle, Maine $\left(46.6528^{\circ} \mathrm{N}, 68.0109^{\circ} \mathrm{W}\right)$ from potato (Solanum tuberosum, Family: Solanaceae) fields and then maintained on excised potato foliage in the laboratory. Until they were used in trials, lady beetles and aphid colonies were housed separately in ventilated, $0.95 \mathrm{~L}$ ball glass jars (Jarden Home Brands, Inc., Daleville, IN, USA) held within Percival I-33VL Intellus environmental chambers (Percival Scientific, Inc., Perry, IA, USA) at 16 (light) $: 8$ (dark) hour photoperiod. The temperature was maintained at $20 \pm 1^{\circ} \mathrm{C}$ during both the photophase and scotophase. Trials were conducted from May 16 to September 8, 2006.

2.3. Competition Trials with Paired Lady Beetles. Each trial took place in an observation arena under a clear, ventilated plastic container $(8.9-\mathrm{cm}$ diameter and $9.5-\mathrm{cm}$ height), which was turned upside down and placed inside the bottom of a Petri dish. For each container, a cut potato leaf was placed in a small plastic vial with water. Using a paintbrush, 4 adult wingless aphids were placed on the upper surface of the leaf. Aphid number was chosen based on a previous study [36] in which lady beetles consumed between $5.33 \pm 0.4271$ ( $P$. quatuordecimpunctata) and $9.17 \pm 0.2039$ (H. axyridis) adult potato aphids in a 24-hour period. Therefore, we believe that four aphids provided an adequate, but not overabundant, food supply. The vial containing the vegetation and aphids was then placed in an upright position inside the observation arena. Adult lady beetles were transferred to a different observation arena by allowing each lady beetle to crawl on to the tip of a paintbrush and then onto the interior of the arena. After a 10-minute period of adjustment, the cover holding the lady beetle(s) was switched with the cover under which the vial holding the leaf and aphids was housed, simultaneously exposing the lady beetle(s) to the aphids. Trials were conducted for 45 minutes. Time to prey discovery (of the first aphid), number of prey consumed by each beetle (documented to 0.25 aphid when the entire aphid was not consumed), and behavior (as a count of aggression delivered and received by each beetle in each trial) were recorded. The following behaviors were considered aggressive: chasing, grasping, biting, climbing upon, and attempting to or successfully stealing prey. Ten trials were conducted in random order, with individuals of each species and with pairs of all combinations of each species, including conspecific pairings.

2.4. Prey Consumption and Discovery Time by Single Lady Beetles. To serve as a comparison with the paired trials described above, aphid consumption and time to prey discovery was also documented in trials with single lady beetles. These trials were conducted following the same protocol as described above, but with one individual introduced in each arena. Ten trials were conducted with each of the seven lady beetle species. 
TABLE 1: Mean ( \pm SE) aphid consumption (number of aphids), prey discovery time (minutes), and aggression delivered (number of occurrences) by seven lady beetle species during laboratory trials. The data were pooled for all trials conducted with a given species (see text for details). Means in each column followed by the same letter are not significantly different from each other (Tukey's HSD tests, $P<0.05$ ). Nonnative species are printed in bold font.

\begin{tabular}{|c|c|c|c|c|c|c|}
\hline & \multicolumn{3}{|c|}{ Aphid consumption } & \multirow{2}{*}{$\begin{array}{c}\text { Aggression } \\
\text { delivered } \\
\text { Other species }\end{array}$} & \multicolumn{2}{|c|}{ Prey discovery time } \\
\hline & Alone & Same species & Other species & & Same species & Other species \\
\hline C. trifasciata & $1.30 \pm 0.34 b$ & $1.55 \pm 0.21 \mathrm{ab}$ & $1.78 \pm 0.17 \mathrm{ab}$ & $0.22 \pm 0.05 b$ & $15.95 \pm 3.11 \mathrm{ab}$ & $16.47 \pm 2.02 b$ \\
\hline C. maculata & $1.60 \pm 0.37 \mathrm{ab}$ & $1.55 \pm 0.20 \mathrm{ab}$ & $1.42 \pm 0.16 \mathrm{bcd}$ & $0.23 \pm 0.06 \mathrm{~b}$ & $20.30 \pm 2.75 a$ & $17.80 \pm 2.01 b$ \\
\hline H. convergens & $1.20 \pm 0.29 b$ & $1.35 \pm 0.20 \mathrm{ab}$ & $1.30 \pm 0.14 \mathrm{bcd}$ & $0.20 \pm 0.05 b$ & $18.40 \pm 3.07 \mathrm{a}$ & $19.18 \pm 2.18 b$ \\
\hline C. septempunctata & $1.70 \pm 0.42 \mathrm{ab}$ & $1.50 \pm 0.28 \mathrm{ab}$ & $1.48 \pm 0.17 \mathrm{abc}$ & $0.13 \pm 0.04 b$ & $18.70 \pm 3.75 a$ & $20.80 \pm 2.33 \mathrm{ab}$ \\
\hline H. axyridis & $2.70 \pm 0.30 \mathrm{a}$ & $1.95 \pm 0.23 \mathrm{a}$ & $2.10 \pm 0.17 \mathrm{a}$ & $0.57 \pm 0.06 \mathrm{a}$ & $6.35 \pm 1.47 \mathrm{~b}$ & $13.23 \pm 1.99 b$ \\
\hline H. variegata & $0.70 \pm 0.26 b$ & $0.75 \pm 0.12 \mathrm{ab}$ & $0.84 \pm 0.12 d$ & $0.13 \pm 0.04 b$ & $24.90 \pm 3.33 \mathrm{a}$ & $28.13 \pm 2.13 \mathrm{a}$ \\
\hline P. quatuordecimpunctata & $1.10 \pm 0.23 b$ & $1.03 \pm 0.13 \mathrm{~b}$ & $0.94 \pm 0.11 \mathrm{~cd}$ & $0.33 \pm 0.06 \mathrm{~b}$ & $17.85 \pm 3.39 \mathrm{a}$ & $20 \pm 2.18 \mathrm{ab}$ \\
\hline$N$ & 10 & 20 & 60 & 60 & 20 & 60 \\
\hline$P$ & 0.0146 & 0.0122 & $<0.0001$ & $<0.0001$ & 0.0002 & $<0.0001$ \\
\hline$F$ & 2.90 & 2.85 & 5.99 & 6.27 & 4.76 & 5.56 \\
\hline DF & 6,63 & 6,133 & 6,413 & 6,413 & 6,133 & 4,413 \\
\hline
\end{tabular}

2.5. Measurements of Lady Beetle Weight and Size. Because differences in predator size have been used in some studies to explain differences in competition $[6,17,53,54]$, the weight and volume of 20 lady beetles of each species were documented. The weight of each beetle was determined to the 0.0001 gram using an electronic Ohaus Adventurer Balance AR2140 (Ohaus Corp., Pine Brook, NJ, USA). Width, length, and height were measured using a ruler mounted in the eyepiece of a Stereoscopic Zoom Microscope SMZ800 (Nikon Instruments Inc., Melville, NY, USA) at 10x magnification. Volume was estimated by multiplying width (across the pronotum, dorsal side), length (from the frons of the head to the end of the elytra, dorsal side), and height (the greatest height below the elytra, laterally).

2.6. Statistical Analyses. The Wilk-Shapiro test (PROC UNIVARIATE; SAS Institute, Inc. 2002) was used to test data normality. Data were transformed using rank transformations [55]. Untransformed data were used to calculate the means and standard errors reported in this paper.

Behavioral data were analyzed using one-way ANOVAs followed by Tukey's HSD tests (PROC GLM, SAS Institute, Inc. 2002). First, we compared the overall differences among the species for beetles that were held alone, paired with conspecifics, and paired with heterospecifics (all species other than the species of interest pooled together). Lady beetle species were used as the main effect (Table 1). Secondly, we tested the effects of the competition context (beetle held alone, paired with conspecifics, or paired individually with each of the heterospecific species) separately for each lady beetle species. Competition contexts were used as the main effect (Tables 2-4). Aphid consumption, prey discovery time, aggression received, and aggression delivered were used as dependent variables in both analyses.
TABLE 2: Number of aphids (mean $\pm \mathrm{SE}$ ) consumed by C. trifasciata and C. maculata in different competition contexts (see text for details). Means in each column followed by the same letter are not significantly different from each other (Tukey's HSD tests, $P<$ 0.05). Nonnative species are printed in bold font.

\begin{tabular}{lcc}
\hline $\begin{array}{l}\text { Competition } \\
\text { context }\end{array}$ & C. trifasciata & C. maculata \\
\hline Alone & $1.30 \pm 0.34 \mathrm{ab}$ & $1.60 \pm 0.37 \mathrm{ab}$ \\
C. trifasciata & $1.70 \pm 0.34 \mathrm{ab}$ & $0.40 \pm 0.22 \mathrm{~b}$ \\
C. trifasciata* & $1.40 \pm 0.27 \mathrm{ab}$ & $\mathrm{N} / \mathrm{A}$ \\
C. maculata & $2.60 \pm 0.37 \mathrm{ab}$ & $1.60 \pm 0.31 \mathrm{ab}$ \\
C. maculata* & $\mathrm{N} / \mathrm{A}$ & $1.50 \pm 0.27 \mathrm{ab}$ \\
C. septempunctata & $1.00 \pm 0.42 \mathrm{~b}$ & $1.80 \pm 0.36 \mathrm{a}$ \\
H. axyridis & $1.30 \pm 0.37 \mathrm{ab}$ & $1.00 \pm 0.27 \mathrm{ab}$ \\
H. convergens & $2.60 \pm 0.31 \mathrm{a}$ & $1.55 \pm 0.26 \mathrm{ab}$ \\
H. variegata & $1.20 \pm 0.36 \mathrm{ab}$ & $1.95 \pm 0.51 \mathrm{a}$ \\
$P$. quatuordecim- & $2.00 \pm 0.39 \mathrm{ab}$ & $1.80 \pm 0.42 \mathrm{ab}$ \\
punctata & 0.0073 & 0.0262 \\
$P$ & 2.87 & 2.33 \\
$F$ & 8,81 & 8,81 \\
\hline DF & & \\
\hline
\end{tabular}

${ }^{*}$ When beetles were paired with conspecifics, the data are listed separately for each beetle in the pair.

Correlation analysis (PROC CORR; SAS Institute Inc. 2002) was used to test associations between aphid consumption, prey discovery time, aggression delivered, and aggression received. The analyses were conducted both within each species (e.g., correlation between aphid consumption and prey discovery time for $H$. axyridis), as well as between the two paired species (e.g., correlation between aphid consumption by $H$. axyridis and C. septempunctata) or the two 
TABLE 3: Number of aggression events (mean \pm SE) delivered by $H$. axyridis and $H$. variegata in different competition contexts (see text for details). Means in each column followed by the same letter are not significantly different from each other (Tukey's HSD tests, $P<0.05)$. Nonnative species are printed in bold font.

\begin{tabular}{lcc}
\hline Competition context & H. axyridis & H. variegata \\
\hline H. axyridis & $0.10 \pm 0.10 \mathrm{~b}$ & $0.50 \pm 0.17 \mathrm{a}$ \\
H. axyridis* & $0.10 \pm 0.10 \mathrm{~b}$ & N/A \\
C. maculata & $0.60 \pm 0.16 \mathrm{ab}$ & $0.10 \pm 0.10 \mathrm{~b}$ \\
C. septempunctata & $0.10 \pm 0.10 \mathrm{~b}$ & $0.00 \pm 0.00 \mathrm{~b}$ \\
C. trifasciata & $0.80 \pm 0.13 \mathrm{a}$ & $0.00 \pm 0.00 \mathrm{~b}$ \\
H. convergens & $0.70 \pm 0.15 \mathrm{ab}$ & $0.00 \pm 0.00 \mathrm{~b}$ \\
H. variegata & $0.50 \pm 0.17 \mathrm{ab}$ & $0.00 \pm 0.00 \mathrm{~b}$ \\
H. variegata* & $\mathrm{N} / \mathrm{A}$ & $0.00 \pm 0.00 \mathrm{~b}$ \\
P. quatuordecim- & $0.70 \pm 0.16 \mathrm{ab}$ & $0.20 \pm 0.13 \mathrm{ab}$ \\
punctata & 0.0003 & $<0.0001$ \\
$P$ & 4.70 & 4.72 \\
$F$ & 7,72 & 7,72 \\
DF &
\end{tabular}

${ }^{*}$ When beetles were paired with conspecifics, the data are listed separately for each beetle in the pair.

individuals of the same species in case of conspecific trials. Most of the correlations between aphid consumption and prey discovery time were statistically significant. Therefore, for the ease of interpretation, their results are reported separately (Table 5) from statistically significant comparisons between all other combinations of variables (Table 6).

Weights and volumes of different lady beetle species were compared using one-way ANOVA (PROC GLM, SAS Institute, Inc. 2002). Means were separated by Tukey's HSD tests.

\section{Results}

Aphid consumption was significantly different among the species whether the beetles were held alone, paired with conspecifics, or paired with heterospecifics (Table 1). Harmonia axyridis generally consumed the most aphids, while $P$. quatuordecimpunctata and $H$. variegata consumed the least. Also, $H$. axyridis was the most aggressive species towards other lady beetles when held with heterospecifics (Table 1). No difference in delivered aggression was detected among the species paired with conspecifics (d.f. $=6,133, F=2.07, P=0.1544$ ). The overall amount of received aggression was similar among the tested species $(P>0.15)$.

Prey discovery time did not differ among species when the beetles were held alone (d.f. $=6,63, F=1.01, P=0.4273$ ). However, in the presence of conspecifics, $H$. axyridis found aphids quicker compared to the other species (Table 1). In the trials with heterospecifics, $H$. variegata discovered prey slower than all other species except C. septempunctata and $P$. quatuordecimpunctata (Table 1).

Competition context affected aphid consumption for two of the tested lady beetle species (Table 2). Coccinella trifasciata consumed fewer aphids when paired with $C$. septempunctata than when paired with $H$. convergens, while
C. maculata consumed fewer aphids when paired with C. trifasciata than when paired with C. septempunctata or $H$. variegata. Prey discovery time did not vary within any of the tested species regardless of the competition context $(P>0.2)$.

Harmonia axyridis exhibited significantly more aggression towards $C$. trifasciata than towards the other lady beetle species (Table 3). Interestingly, H. variegata, which was a rather peaceful species in our trials, significantly increased its level of aggression when paired with $H$. axyridis (Table 3 ). Coccinella trifasciata, $H$. convergens, $H$. variegata, and $P$. quatuordecimpunctata received different amounts of aggression from different lady beetle species (Table 4). A statistically significant difference was also detected for C. maculata, but the effect was relatively weak, inconsistent, and its biological significance is uncertain (Table 4). Beetles from all five aforementioned species received more aggression from $H$. axyridis compared to at least one other species with which they were paired. Hippodamia variegata also received as much aggression from $P$. quatuordecimpunctata as from $H$. axyridis (Table 4).

Not surprisingly, aphid consumption was negatively correlated with prey discovery time (Table 5). In other words, the beetles that found their prey the most quickly consumed the most. The only exceptions were $C$. trifasciata paired with C. maculata, $H$. convergens paired with $H$. axyridis, and $H$. axyridis paired with $P$. quatuordecimpunctata. Correlation coefficients were marginally significant for $C$. maculata paired with $H$. axyridis, $H$. axyridis paired with $C$. trifasciata, and P. quatuordecimpunctata paired with C. maculata (Table 5).

Correlation analyses also revealed a number of strong relationships between other measured parameters (Table 6). In six trials, aphid consumption by one species was negatively correlated with aphid consumption by the other species confined in the same arena. Similarly, there were three cases of negative correlations between prey discovery times by two beetles in a pair. In five comparisons, aphid consumption by one species was positively correlated with prey discovery time by the other species. Aggressive behavior increased aphid consumption for C. maculata when paired with C. trifasciata, and for $H$. convergens when paired with $H$. axyridis. However, prey discovery time for C. maculata increased with increased aggression against $C$. septempunctata. Receiving aggression from $P$. quatuordecimpunctata significantly decreased aphid consumption by C. septempunctata. Similarly, prey discovery time for three aphid species increased as they received more aggression from another beetle in the pair (Table 6).

Coccinella septempunctata was the largest of the species tested, closely followed by H. axyridis (Table 7). Hippodamia variegata was the smallest.

\section{Discussion}

Results of the present study suggest the existence of asymmetric competitive interactions among the tested lady beetle species. There were significant differences in aphid consumption and prey discovery times among the species, and numerous occasions of aggressive encounters among the beetles confined in the observation arenas. The nature and strength 
TABle 4: Number of aggression events (mean \pm SE) received by C. trifasciata, C. maculata, H. convergens, H. variegata, and P. quatuordecimpunctata in different competition contexts (see text for details). Means in each column followed by the same letter are not significantly different from each other (Tukey's HSD tests, $P<0.05$ ). Nonnative species are printed in bold font.

\begin{tabular}{|c|c|c|c|c|c|}
\hline & C. trifasciata & C. maculata & H. convergens & H. variegata & $\begin{array}{l}\text { P. quatordecim- } \\
\text { punctata }\end{array}$ \\
\hline C. trifasciata & $0.20 \pm 0.13 b$ & $0.30 \pm 0.15 \mathrm{ab}$ & $0.20 \pm 0.13 \mathrm{ab}$ & $0.10 \pm 0.10 b$ & $0.30 \pm 0.15 \mathrm{ab}$ \\
\hline C. trifasciata* & $0.30 \pm 0.15 \mathrm{ab}$ & N/A & N/A & N/A & N/A \\
\hline C. maculata & $0.20 \pm 0.13 b$ & $0.00 \pm 0.00 \mathrm{~b}$ & $0.20 \pm 0.13 \mathrm{ab}$ & $0.30 \pm 0.15 \mathrm{ab}$ & $0.10 \pm 0.10 \mathrm{~b}$ \\
\hline C. maculata* & N/A & $0.10 \pm 0.10 \mathrm{ab}$ & N/A & N/A & N/A \\
\hline C. septempunctata & $0.20 \pm 0.13 b$ & $0.10 \pm 0.10 \mathrm{ab}$ & $0.30 \pm 0.15 \mathrm{ab}$ & $0.00 \pm 0.00 \mathrm{~b}$ & $0.10 \pm 0.10 \mathrm{~b}$ \\
\hline H. axyridis & $0.80 \pm 0.13 a$ & $0.60 \pm 0.16 \mathrm{a}$ & $0.70 \pm 0.15 \mathrm{a}$ & $0.50 \pm 0.17 \mathrm{a}$ & $0.70 \pm 0.15 \mathrm{a}$ \\
\hline H. convergens & $0.00 \pm 0.00 \mathrm{~b}$ & $0.30 \pm 0.15 \mathrm{ab}$ & $0.10 \pm 0.10 \mathrm{~b}$ & $0.20 \pm 0.13 \mathrm{ab}$ & $0.20 \pm 0.13 \mathrm{ab}$ \\
\hline H. convergens* & N/A & N/A & $0.10 \pm 0.10 \mathrm{~b}$ & N/A & N/A \\
\hline H. variegata & $0.00 \pm 0.00 \mathrm{~b}$ & $0.10 \pm 0.10 \mathrm{ab}$ & $0.00 \pm 0.00 \mathrm{~b}$ & $0.00 \pm 0.00 \mathrm{~b}$ & $0.20 \pm 0.13 \mathrm{ab}$ \\
\hline H. variegata* & $\mathrm{N} / \mathrm{A}$ & N/A & $\mathrm{N} / \mathrm{A}$ & $0.00 \pm 0.00 \mathrm{~b}$ & N/A \\
\hline P. quatuordecimpunctata & $0.40 \pm 0.16 \mathrm{ab}$ & $0.20 \pm 0.13 \mathrm{ab}$ & $0.30 \pm 0.15 \mathrm{ab}$ & $0.50 \pm 0.17 \mathrm{a}$ & $0.10 \pm 0.10 \mathrm{~b}$ \\
\hline P. quatuordecimpunctata* & $\mathrm{N} / \mathrm{A}$ & N/A & N/A & N/A & $0.10 \pm 0.10 \mathrm{~b}$ \\
\hline$P$ & 0.0012 & 0.0298 & 0.0132 & 0.0028 & 0.0170 \\
\hline$F$ & 3.89 & 1.79 & 2.39 & 3.22 & 2.88 \\
\hline $\mathrm{DF}$ & 7,72 & 7,72 & 7,72 & 7,72 & 7,72 \\
\hline
\end{tabular}

${ }^{*}$ When beetles were paired with conspecifics, the data are listed separately for each beetle in the pair.

TABLE 5: Correlations between aphid consumption and prey discovery time for single and paired lady beetles in trials $(N=10)$. Each row represents the relationship between aphid consumption and prey discovery time for the species in the left column when it was alone or paired with the species in the first row of the table. Ct: Coccinella trifasciata, Cm: Coleomegilla maculata, Hc: Hippodamia convergens, Cs: Coccinella septempunctata, Ha: Harmonia axyridis, Hv: Hippodamia variegata, Pq: Propylea quatuordecimpunctata. Nonnative species are printed in bold font.

\begin{tabular}{lccccccccc}
\hline & & Alone & $\mathrm{Ct}$ & $\mathrm{Cm}$ & $\mathrm{Hc}$ & $\mathrm{Cs}$ & $\mathrm{Ha}$ & $\mathrm{Hv}$ & $\mathrm{Pq}$ \\
\hline $\mathrm{Ct}$ & $r$ & -0.8698 & -0.7745 & -0.3644 & -0.8675 & -0.8541 & -0.7642 & -0.9107 & -0.7571 \\
& $P$ & 0.0011 & $<0.0001$ & 0.3005 & 0.0011 & 0.0017 & 0.0101 & 0.0002 & 0.0112 \\
$\mathrm{Cm}$ & $r$ & -0.9524 & -0.7942 & -0.8559 & -0.9011 & -0.6469 & -0.6235 & -0.8016 & -0.7745 \\
& $P$ & $<0.0001$ & 0.0061 & $<0.0001$ & 0.0004 & 0.0432 & 0.0541 & 0.0053 & 0.0085 \\
$\mathrm{Hc}$ & $r$ & -0.7994 & -0.8708 & -0.8199 & -0.9091 & -0.9039 & -0.5518 & -0.9431 & -0.9184 \\
& $P$ & 0.0055 & 0.0010 & 0.0037 & $<0.0001$ & 0.0003 & 0.0982 & $<0.0001$ & 0.0002 \\
$\mathrm{Cs}$ & $r$ & -0.8420 & -0.8009 & -0.8193 & -0.8701 & -0.8735 & -0.9240 & -0.9066 & -0.8609 \\
& $P$ & 0.0022 & 0.0054 & 0.0037 & 0.0011 & $<0.0001$ & 0.0001 & 0.0003 & 0.0014 \\
$\mathrm{Ha}$ & $r$ & -0.9389 & -0.6010 & -0.7980 & -0.8140 & -0.6836 & -0.7743 & -0.9708 & -0.2439 \\
& $P$ & $<0.0001$ & 0.0661 & 0.0057 & 0.0042 & 0.0293 & $<0.0001$ & $<0.0001$ & 0.4970 \\
$\mathrm{Hv}$ & $P$ & -0.9447 & -0.7891 & -0.8894 & -0.9322 & -0.7487 & -0.8316 & -0.8647 & -0.8033 \\
& $P$ & $<0.0001$ & 0.0067 & 0.0006 & $<0.0001$ & 0.0127 & 0.0029 & $<0.0001$ & 0.0051 \\
$\mathbf{P q}$ & $P$ & -0.8818 & -0.8734 & -0.6182 & -0.7900 & -0.8852 & -0.6361 & -0.8284 & -0.7502 \\
& $P$ & 0.0011 & 0.0010 & 0.0568 & 0.0065 & 0.0007 & 0.0480 & 0.0031 & 0.0001 \\
\hline
\end{tabular}

of the observed interactions varied depending on the species involved.

Harmonia axyridis was the most successful aphid predator in our study, being able to find aphids quicker and consume more of them compared to most other lady beetle species. Furthermore, $H$. axyridis was by far the most aggressive of the tested species. These observations are consistent with a number of studies that have documented the superior competitive abilities of $H$. axyridis among lady beetle species $[6,17,24,26,28,31,56,57]$. A superior competitive ability of invasive species to utilize resources over native species has been also documented in numerous other systems [58-61].

Interestingly, it took about twice as long for $H$. axyridis to find aphids when paired with heterospecifics than when paired with conspecifics (Table 1). It is possible that attacking heterospecifics distracted them from searching for aphids. Indeed, $H$. axyridis attacked heterospecifics 5-8 times more often than conspecifics (Table 3 ) although the differences were not always statistically significant. The aphid consumption data suggest that such a strategy paid off. Similarly, 
TABLE 6: Additional significant correlations between aphid consumption, prey discovery time, aggression delivered, and aggression received by lady beetles in trials $(N=10)$. Nonnative species are printed in bold font.

\begin{tabular}{|c|c|c|c|}
\hline Correlation between: & And: & & \\
\hline Aphid consumption & Aphid consumption & $r$ & $P$ \\
\hline C. septempunctata & C. trifasciata & -0.9049 & 0.0002 \\
\hline C. trifasciata & H. convergens & -0.7356 & 0.0127 \\
\hline C. maculata & H. axyridis & -0.7098 & 0.0112 \\
\hline C. septempunctata & H. convergens & -0.8195 & 0.0053 \\
\hline H. axyridis & H. convergens & -0.9133 & 0.0003 \\
\hline H. axyridis & P. quatuordecimpunctata & -0.8497 & 0.0020 \\
\hline Prey discovery time & Prey discovery time & $r$ & $P$ \\
\hline C. septempunctata & C. trifasciata & -0.7653 & 0.0085 \\
\hline C. septempunctata & H. convergens & -0.8138 & 0.0030 \\
\hline H. convergens & P. quatuordecimpunctata & -0.7001 & 0.0143 \\
\hline Aphid consumption & Prey discovery time & $r$ & $P$ \\
\hline C. trifasciata & C. septempunctata & 0.8350 & 0.0017 \\
\hline C. septempunctata & H. convergens & 0.7069 & 0.0002 \\
\hline C. septempunctata & C. trifasciata & 0.7665 & 0.0112 \\
\hline H. convergens & C. septempunctata & 0.8344 & 0.0022 \\
\hline P. quatuordecimpunctata & H. variegata & 0.7107 & 0.0088 \\
\hline Aphid consumption & Aggression delivered towards & $r$ & $P$ \\
\hline C. maculata & C. trifasciata & 0.7994 & 0.0063 \\
\hline H. convergens & H. axyridis & 0.7327 & 0.0029 \\
\hline Aphid consumption & Aggression received from & $r$ & $P$ \\
\hline C. septempunctata & P. quatuordecimpunctata & -0.7812 & 0.0080 \\
\hline Prey discovery time & Aggression delivered towards & $r$ & $P$ \\
\hline C. maculata & C. septempunctata & 0.9225 & $<0.0001$ \\
\hline Prey discovery time & Aggression received from & $r$ & $P$ \\
\hline C. maculata & C. septempunctata & 0.8511 & 0.0017 \\
\hline H. convergens & C. maculata & 0.8370 & 0.0002 \\
\hline C. septempunctata & P. quatuordecimpunctata & 0.8392 & 0.0028 \\
\hline Aggression delivered by & or Aggression received by & $r$ & $P$ \\
\hline C. trifasciata & C. trifasciata & 0.7003 & 0.0004 \\
\hline
\end{tabular}

Michaud [6] found H. axyridis to be a highly evolved interspecific competitor in the Florida citrus ecosystem.

Harmonia axyridis data generally agree with our hypothesis that recently introduced lady beetle species that replace native species over time are more aggressive aphid predators. However, we did not observe the same situation for the other three nonnative species. There was no distinct dichotomy between supposedly more aggressive nonnative species and supposedly more docile native species. Also, except for the generally superior $H$. axyridis, there was no obvious dominance hierarchy among the other tested species.

The native lady beetle species used in the current study, C. maculata, C. trifasciata, and $H$. convergens are currently numerous in Maine [21]. Native species, Coccinella transversoguttata (Brown) and Hippodamia tredecimpunctata tibialis (Say), that have experienced declines in abundance since nonnative lady beetle introductions [9] were excluded be- cause they were not easily found in numbers sufficient for testing [21]. It would be interesting and valuable to pair native species once numerous in Maine with both the now common nonnative species and the native species that still persist.

Among the species tested, C. septempunctata, C. trifasciata and C. maculata generally followed $H$. axyridis in aphid consumption. Coccinella septempunctata and $H$. axyridis were also the heaviest and largest species among the seven species tested (Table 7). Despite C. septempunctata's large size and being among the species consuming the most aphids, C. septempunctata generally did not deliver or receive more aggression than other species. Larger lady beetle species have been shown to be competitively favored over smaller ones $[6,17,53,54]$, possibly because they are able to consume more due to their larger size, or perhaps because their size is advantageous in direct fighting. Coccinella septempunctata has also been documented to deter aggression by ants 
TABle 7: Mean $( \pm \mathrm{SE})$ weight $(\mathrm{mg})$ and volume $\left(\mathrm{mm}^{3}\right)$ of lady beetle species $(N=20)$ used in laboratory trials. Means in each column with the same letter are not significantly different (Tukey's HSD tests, $P<0.05)$. Nonnative species are printed in bold font.

\begin{tabular}{lcc}
\hline & Weight & Volume \\
\hline C. trifasciata & $1.04 \pm 0.0007 \mathrm{c}$ & $20.41 \pm 1.2005 \mathrm{~d}$ \\
C. maculata & $0.91 \pm 0.0008 \mathrm{c}$ & $15.10 \pm 0.8356 \mathrm{de}$ \\
H. convergens & $0.87 \pm 0.0009 \mathrm{c}$ & $32.43 \pm 1.8409 \mathrm{c}$ \\
C. septempunctata & $2.25 \pm 0.0017 \mathrm{a}$ & $78.87 \pm 2.6835 \mathrm{a}$ \\
H. axyridis & $1.68 \pm 0.0015 \mathrm{~b}$ & $66.30 \pm 2.4081 \mathrm{~b}$ \\
H. variegata & $0.40 \pm 0.0004 \mathrm{~d}$ & $8.64 \pm 0.5435 \mathrm{e}$ \\
P. quatuordecim- & $0.63 \pm 0.0005 \mathrm{dc}$ & $12.87 \pm 0.8090 \mathrm{e}$ \\
punctata & $<0.0001$ & $<0.0001$ \\
$P$ & 38.63 & 280.85 \\
$F$ & 6,133 & 6,133 \\
DF & &
\end{tabular}

chemically by producing a defensive alkaloid and bleeding reflectively $[62,63]$. It is possible that chemical defense is also used by C. septempunctata to prevent aggression from other coccinellids.

It is worth noting that $H$. axyridis, C. septempunctata, $H$. convergens, $H$. variegata, and $P$. quatuordecimpunctata showed no difference in aphid consumption and prey discovery time whether they were kept alone or paired with any other species tested in the study, including conspecifics (data not shown). Perhaps if a given species is an efficient predator that can find and consume aphids quickly, its ability to acquire prey may not be significantly hindered by the presence of other lady beetles. Prey consumption by $C$. trifasciata and $C$. maculata, on the other hand, differed depending on which species they were paired with.

Significant negative correlations between the numbers of aphids consumed and prey discovery times in paired trials (Table 6) confirm the existence of competitive interactions. Furthermore, we detected a number of significant positive correlations between the number of aphids consumed by one beetle in a pair and prey discovery time by the other beetle in the pair. In other words, the longer it took a beetle to discover the prey, the more aphids its competitor could consume.

Increased aggression delivered by C. maculata and $H$. convergens (Table 6) was correlated with increased aphid consumption by those species in trials with $C$. trifasciata and H. axyridis, respectively. In those cases, aggression may have helped deter other species from consuming prey. On the contrary, increased aggression by C. maculata was correlated with its own increased prey discovery time, suggesting that it was distracted from foraging.

Receiving aggression from P. quatuordecimpunctata increased prey discovery time and decreased aphid consumption for C. septempunctata (Table 6). Similarly, prey discovery time increased for $H$. convergens with the increase in aggression it received from C. maculata, and for C. septempunctata with the increased aggression it received from $P$. quatuordecimpunctata. In a conspecific pairing of C. trifasciata, aggression received by one conspecific was correlated with the aggression it delivered, meaning that aggressive interactions were not one sided, but equally met by the other conspecific.

Overall, our results confirm that behavioral interactions between different lady beetle species affect their ability to secure prey items, with $H$. axyridis generally having a competitive advantage over the other species. Our study was conducted in a relatively simple setting of a laboratory arena with a limited number of aphids. Furthermore, prey choice was limited to a single aphid species. Increased environmental complexity, including variations in prey species and their abundances (including relative abundances of winged and wingless morphs), may modify competitive abilities of and interactions between certain species. Nevertheless, our findings support the idea that behavioral differences in prey discovery, consumption, and intraguild aggressiveness may, in part, lead to reductions in native lady beetle species following the establishment of $H$. axyridis.

\section{Acknowledgments}

The authors thank Erin Porter and Lauren Little for their assistance in the laboratory and Joseph Cannon, John Jemison, Black Bear Food Guild, and Orono Land Trust for providing access to and guidance on their land in order to collect lady beetles. They also thank Frank Drummond and Malcolm Hunter, Jr. for providing comments on the manuscript. This research was supported by the Maine Agricultural and Forest Experiment Station (Hatch ME0846601) and the National Science Foundation's GK-12 Teaching Fellows Program (Grant no. DGE-0231642 to S. Brawley et al.). This is Publication No. 3233 of the Maine Agricultural and Forest Experiment Station.

\section{References}

[1] M. E. N. Majerus, Ladybirds, Harper Collins, London, UK, 1994.

[2] I. Hodek and A. Honek, Ecology of Coccinellidae, Kluwer Academic publisher, Boston, Mass, USA, 1996.

[3] N. Elliott, R. Kieckhefer, and W. Kauffman, "Effects of an invading coccinellid on native coccinellids in an agricultural landscape," Oecologia, vol. 105, no. 4, pp. 537-544, 1996.

[4] M. W. Brown and S. S. Miller, "Coccinellidae (Coleoptera) in apple orchards of eastern West Virginia and the impact of invasion by Harmonia axyridis," Entomological News, vol. 109, no. 2, pp. 163-142, 1998.

[5] M. Colunga-Garcia and S. H. Gage, "Arrival, establishment, and habitat use of the multicolored Asian lady beetle (Coleoptera: Coccinellidae) in a Michigan landscape," Environmental Entomology, vol. 27, no. 6, pp. 1574-1580, 1998.

[6] J. P. Michaud, "Invasion of the Florida citrus ecosystem by Harmonia axyridis (Coleoptera: Coccinellidae) and asymmetric competition with a native species, Cycloneda sanguinea," Environmental Entomology, vol. 31, no. 5, pp. 827-835, 2002.

[7] M. W. Brown, "Intraguild responses of aphid predators on apple to the invasion of an exotic species, Harmonia axyridis," BioControl, vol. 48, no. 2, pp. 141-153, 2003.

[8] W. J. Turnock, I. L. Wise, and F. O. Matheson, "Abundance of some native coccinellines (Coleoptera: Coccinellidae) before 
and after the appearance of Coccinella septempunctata," Canadian Entomologist, vol. 135, no. 3, pp. 391-404, 2003.

[9] A. Alyokhin and G. Sewell, "Changes in a lady beetle community following the establishment of three alien species," Biological Invasions, vol. 6, no. 4, pp. 463-471, 2004.

[10] A. Alyokhin, F. A. Drummond, and G. Sewell, "Density-dependent regulation in populations of potato-colonizing aphids," Population Ecology, vol. 47, no. 3, pp. 257-266, 2005.

[11] N. G. Hairston, F. E. Smith, and L. B. Slobodkin, "Community structure, population control, and competition," The American Naturalist, vol. 94, pp. 421-425, 1960.

[12] R. MACARTHUR and R. LEVINS, "Competition, habitat selection, and character displacement in a patchy environment," Proceedings of the National Academy of Sciences of the United States of America, vol. 51, pp. 1207-1210, 1964.

[13] R. MacArthur and R. Levins, "The limiting similarity, convergence, and divergence of coexisting species," The American Naturalist, vol. 101, pp. 377-385, 1967.

[14] E. R. Pianka, Evolutionary Ecology, Harper and Row, NY, New York, USA, 2nd edition, 1978.

[15] J. E. Losey and R. F. Denno, "Positive predator-predator interactions: enhanced predation rates and synergistic suppression of aphid populations," Ecology, vol. 79, no. 6, pp. 2143-2152, 1998.

[16] S. B. Hsu, T. W. Hwang, and Y. Kuang, "Rich dynamics of a ratio-dependent one-prey two-predators model," Journal of Mathematical Biology, vol. 43, no. 5, pp. 377-396, 2001.

[17] H. Yasuda, E. W. Evans, Y. Kajita, K. Urakawa, and T. Takizawa, "Asymmetric larval interactions between introduced and indigenous ladybirds in North America," Oecologia, vol. 141, no. 4, pp. 1432-1939, 2004.

[18] D. M. Nunes and S. M. Hartz, "Feeding dynamics and ecomorphology of Oligosarcus jenynsii (Gunther, 1864) and Oligosarcus robustus (Menezes, 1969) in the Lagoa Fortaleza, Southern Brazil," Brazilian Journal of Biology, vol. 66, no. 1 A, pp. 121-132, 2006.

[19] L. Blaustein and J. M. Chase, "Interactions between mosquito larvae and species that share the same trophic level," Annual Review of Entomology, vol. 52, pp. 489-507, 2007.

[20] S. Gakkhar, B. Singh, and R. K. Naji, "Dynamical behavior of two predators competing over a single prey," BioSystems, vol. 90, no. 3, pp. 808-817, 2007.

[21] C. J. Finlayson, K. M. Landry, and A. V. Alyokhin, "Abundance of native and non-native lady beetles (Coleoptera: Coccinellidae) in different habitats in Maine," Annals of the Entomological Society of America, vol. 101, no. 6, pp. 1078-1087, 2008.

[22] K. Takahashi, "Intra- and interspecifc predations of lady beetles in spring alfalfa fields," Japan Journal of Entomology, vol. 57, pp. 199-203, 1989.

[23] J. Hough-Goldstein, J. Cox, and A. Armstrong, "Podisus maculiventris (Hemiptera: Pentatomidae) predation on ladybird beetles (Coleoptera: Coccinellidae)," Florida Entomologist, vol. 79, pp. 64-68, 1996.

[24] Y. Hironori and S. Katsuhiro, "Cannibalism and interspecific predation in two predatory ladybirds in relation to prey abundance in the field," Entomophaga, vol. 42, no. 1-2, pp. 53$163,1997$.

[25] T. E. Cottrell and K. V. Yeargan, "Intraguild predation between an introduced lady beetle, Harmonia axyridis (Coleoptera: Coccinellidae), and a native lady beetle, Coleomegilla maculata (Coleoptera: Coccinellidae)," Journal of the Kansas Entomological Society, vol. 71, no. 2, pp. 159-163, 1998.

[26] H. Yasuda and N. Ohnuma, "Effect of cannibalism and predation on the larval performance of two ladybird beetles,"
Entomologia Experimentalis et Applicata, vol. 93, no. 1, pp. 6367, 1999.

[27] A. F. G. Dixon, Insect Predator-Prey Dynamic: Ladybird Beetles and Biological Control, Cambridge University Press, Cambridge, UK, 2000.

[28] Y. Kajita, F. Takano, H. Yasuda, and B. K. Agarwala, "Effects of indigenous ladybird species (Coleoptera: Coccinellidae) on the survival of an exotic species in relation to prey abundance," Applied Entomology and Zoology, vol. 35, no. 4, pp. 473-479, 2000.

[29] Y. Sakuratani, Y. Matsumoto, M. Oka et al., "Life history of Adalia bipunctata (Coleoptera: Coccinellidae) in Japan," European Journal of Entomology, vol. 97, no. 4, pp. 555-558, 2000.

[30] L. D. Lynch, H. M. T. Hokkanen, D. Babendreier et al., "Insect biological control and non-target effects: a European perspective," in Evaluating Indirect Ecological Effects of Biological Control, E. Wajnberg, J. K. Scott, and P. C. Quinby, Eds., CABI Publishing, Wallingford, UK, 2001.

[31] H. Yasuda, T. Kikuchi, P. Kindlmann, and S. Sato, "Relationships between attack and escape rates, cannibalism, and intraguild predation in larvae of two predatory ladybirds," Journal of Insect Behavior, vol. 14, no. 3, pp. 373-384, 2001.

[32] P. De Clercq, I. Peeters, G. Vergauwe, and O. Thas, "Interaction between Podisus maculiventris and Harmonia axyridis, two predators used in augmentative biological control in greenhouse crops," BioControl, vol. 48, no. 1, pp. 39-55, 2003.

[33] R. L. Koch, "The multicolored Asian lady beetle, Harmonia axyridis: a review of its biology, uses in biological control, and non-target impacts," Journal of Insect Science, vol. 3, no. 32, pp. 1-16, 2003.

[34] T. Saito and S. Bjørnson, "Horizontal transmission of a microsporidium from the convergent lady beetle, Hippodamia convergens Guérin-Méneville (Coleoptera: Coccinellidae), to three coccinellid species of Nova Scotia," Biological Control, vol. 39, no. 3, pp. 427-433, 2006.

[35] C. J. Finlayson, A. V. Alyokhin, and E. W. Porter, "Interactions of native and non-native lady beetle species (Coleoptera: Coccinellidae) with aphid-tending ants in laboratory arenas," Environmental Entomology, vol. 38, no. 3, pp. 846-855, 2009.

[36] C. Finlayson, A. Alyokhin, S. Gross, and E. Porter, "Differential consumption of four aphid species by four lady beetle species," Journal of insect science, vol. 10, no. 31, pp. 1-10, 2010.

[37] R. D. Gordon, "The coccinellidae (Coleoptera) of America north of Mexico," Journal of the New York Entomological Society, vol. 93, pp. 1-912, 1985.

[38] D. Coderre, E. Lucas, and I. Gagne, "The occurrence of Harmonia axyridis (Pallas) (Coleoptera: Coccinellidae) in Canada," Canadian Entomologist, vol. 127, no. 4, pp. 609-611, 1995.

[39] I. Hodek, Biology of Coccinellidae, Academic, The Hague, Netherlands, 1973.

[40] R. D. Gordon, "The first North American records of Hippodamia variegata (Goeze) (Coleoptera: Coccinellidae)," Journal of the New York Entomological Society, vol. 95, pp. 307-309, 1987.

[41] G. W. Angalet, J. M. Tropp, and A. N. Eggart, "Coccinella septempunctata in the United States: recolonizations and notes on its ecology," Environmental Entomology, vol. 8, pp. 896-901, 1979.

[42] J. B. Chapin and V. A. Brou, "Harmonia axyridis (Pallas) the third species of the genus to be found in the United States (Coleoptera: Coccinellidae)," Proceedings of the Entomological Society of Washington, vol. 93, pp. 630-635, 1991.

[43] W. L. Tedders and P. W. Schaefer, "Release and establishment of Harmonia axyridis (Coleoptera: Cocchinellidae) in 
the southeastern United States," Entomological News, vol. 105, no. 4, pp. 228-243, 1994.

[44] R. D. Gordon and N. Vandenberg, "Field guide to recently introduced species of Coccinellidae (Coleoptera) in North America, with a revised key to North American genera of Coccinellini," Proceedings of the Entomological Society of Washington, vol. 93, pp. 854-864, 1991.

[45] A. G. Wheeler, "Establishment of Hippodamia variegata and new records of Propylea quaruordecimpunctata in the eastern United States," Entomological News, vol. 104, pp. 102-110, 1993.

[46] A. G. Wheeler and C. A. Stoops, "Status and spread of the palearctic lady beetles Hippodamia variegata and Propylea quatuordecimpunctata (Coleoptera: Coccinellidae) in Pennsylvania, 1993-1995," Entomological News, vol. 107, no. 5, pp. 291298, 1996.

[47] E. R. Hoebeke and A. G. Wheeler, "Adventive lady beetles (Coleoptera: Coccinellidae) in the Canadian Maritime Provinces, with new eastern U.S. Records of Harmonia quadripunctata," Entomological News, vol. 107, no. 5, pp. 281-290, 1996.

[48] D. R. Ellis, D. R. Prokrym, and R. G. Adams, "Exotic lady beetle survey in northeastern United States: Hippodamia variegata and Propylea quatuordecimpunctata (Coleoptera: Coccinellidae)," Entomological News, vol. 110, no. 2, pp. 73-84, 1999.

[49] C. M. Cormier, T. A. Forbes, T. A. Jones, R. D. Morrison, and D. B. McCorquodale, "Alien invasion: the status of non-native lady beetles (Coleoptera: Coccinellidae) in industrial Cape Breton, Nova Scotia," Northeastern Naturalist, vol. 7, pp. 241247, 2000.

[50] A. G. Wheeler, "Propylea quatuordecimpunctata: additional records of an adventive lady beetle (Coleoptera: Coccinellidae)," Entomological News, vol. 101, pp. 164-166, 1990.

[51] R. L. Blackman and V. F. Eastop, Aphids on the World's Crops: An Identification and Information Guide, John Wiley \& Sons, New York, NY, USA, 1984.

[52] W. A. Shands, G. W. Simpson, H. E. Wave, and C. C. Gordon, "Importance of arthropod predators in controlling aphids on potatoes in northeastern Maine," University of Maine Technical Bulletin 54, University of Maine, Orono, Me, USA, 1972.

[53] J. J. Obrycki, K. L. Giles, and A. M. Ormord, "Experimental Assessment of Interactions between Larval Coleomegilla maculata and Coccinella septempunctata (Coleoptera: Coccinellidae) in Field Cages," Environmental Entomology, vol. 27, no. 5, pp. 1280-1288, 1998.

[54] S. Sato, A. F. G. Dixon, and H. Yasuda, "Effect of emigration on cannibalism and intraguild predation in aphidophagous ladybirds," Ecological Entomology, vol. 28, no. 5, pp. 628-633, 2003.

[55] W. J. Conover and R. L. Iman, "Rank transformations as a bridge between parametric and non-parametric statistics," American Statistician, vol. 35, pp. 124-129, 1981.

[56] Y. Hironori and S. Katsuhiro, "Cannibalism and interspecific predation in two predatory ladybirds in relation to prey abundance in the field," Entomophaga, vol. 42, no. 1-2, pp. 153-163, 1997.

[57] W. E. Snyder, G. M. Clevenger, and S. D. Eigenbrode, "Intraguild predation and successful invasion by introduced ladybird beetles," Oecologia, vol. 140, no. 4, pp. 559-565, 2004.

[58] G. Melgoza, R. S. Nowak, and R. J. Tausch, "Soil water exploitation after fire: competition between Bromus tectorum (cheatgrass) and two native species," Oecologia, vol. 83 , no. 1 , pp. 7-13, 1990.
[59] K. Petren and T. J. Case, "An experimental demonstration of exploitation competition in an ongoing invasion," Ecology, vol. 77, no. 1, pp. 118-132, 1996.

[60] D. A. Holway, "Competitive mechanisms underlying the displacement of native ants by the invasive argentine ant," Ecology, vol. 80, no. 1, pp. 238-251, 1999.

[61] J. E. Byers, "Competition between two estuarine snails: implications for invasions of exotic species," Ecology, vol. 81, no. 5, pp. 1225-1239, 2000.

[62] B. Tursch, D. Daloze, M. Dupont, J. M. Pasteels, and M. C. Tricot, "A defense alkaloid in a carnivorous beetle," Experientia, vol. 27, no. 12, pp. 1380-1381, 1971.

[63] A. P. Bhatkar, "Orientation and defense of ladybeetles (Coleoptera, Coccinellidae) following ant trails in search of aphids," Folia Entomologica Mexicana, vol. 53, pp. 75-85, 1982. 

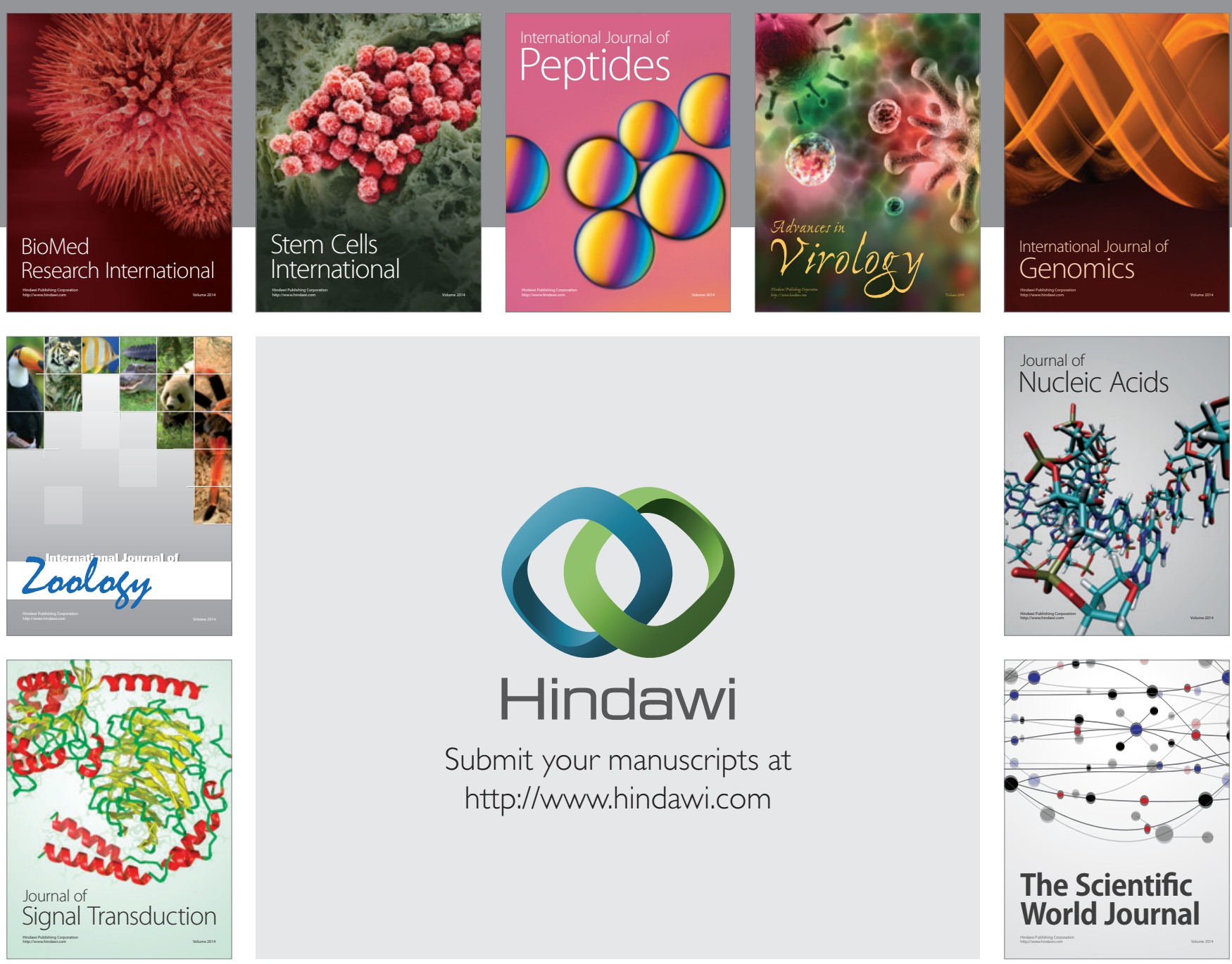

Submit your manuscripts at

http://www.hindawi.com
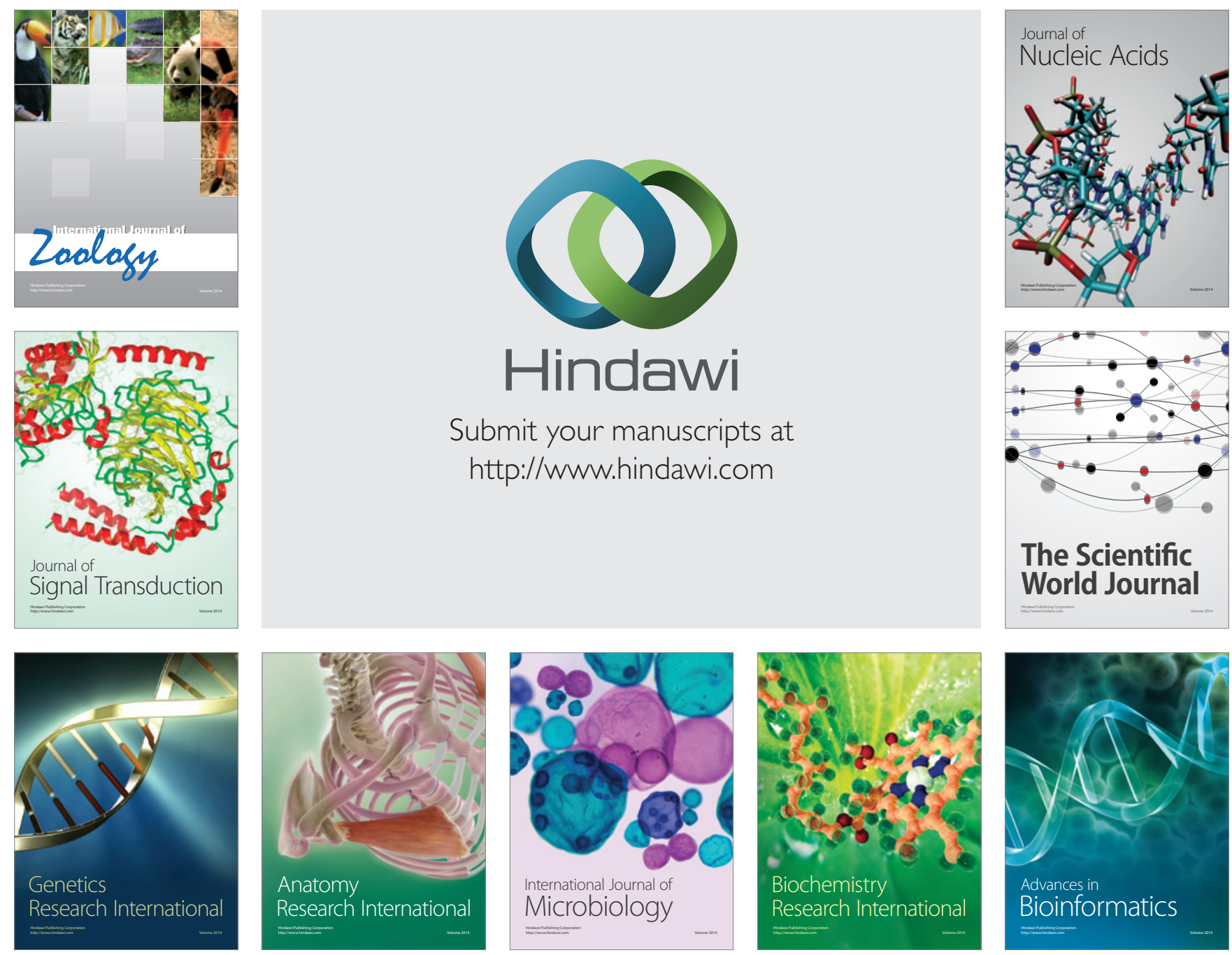

The Scientific World Journal
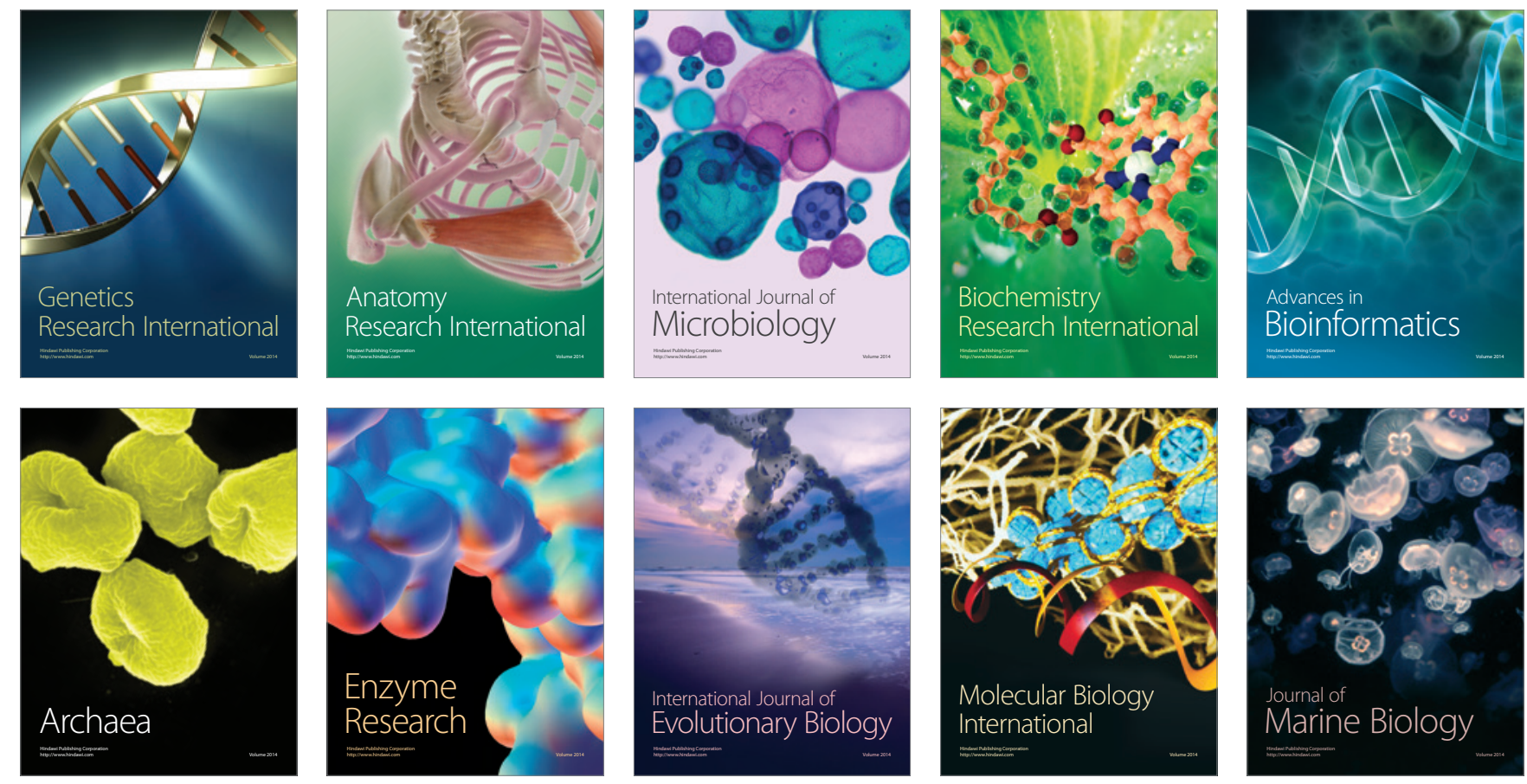